\title{
Cost-Effective Restructuring Based on Process Approach
}

\author{
Ivan Todorović ${ }^{1}$, Stefan Komazec ${ }^{1}$, Miha Marič ${ }^{2}$, Jovan Krivokapić ${ }^{1}$
}

\author{
${ }^{1}$ University of Belgrade, Faculty of Organizational Sciences, 154 Jove Ilića Str., 11000 Belgrade, Serbia, \\ ivan.todorovic@fon.bg.ac.rs, komazec@fon.bg.ac.rs, krivokapicj@fon.bg.ac.rs \\ ${ }^{2}$ University of Maribor, Faculty of Organizational Sciences, Kidričeva cesta 55a, 4000 Kranj, Slovenia, \\ miha.maric@fov.uni-mb.si
}

\begin{abstract}
Different authors agree that designing the organizational structure in accordance with the business processes can bring numerous advantages, which improve business performance of the organizational system. This article aims to show how cost-effective restructuring, through modification of organizational structure according to business processes that exist in the organization, can bring numerous benefits. Successful implementation of process organizational model does not necessarily demand large investments, but only adequate structural changes and internal reorganization. The data used in this paper were gathered during the project of restructuring one transportation company from Belgrade, which consulting team from Faculty of Organizational Sciences, University of Belgrade, performed in year 2012.
\end{abstract}

Keywords: organizational structure, business process, restructuring, organizational change, process organizational model

\section{Introduction}

Different authors identify organizational structure as one of the key elements in every organization (Kates and Galbraith, 2007; Waterman and Peters, Phillips, 1980). There are two diametrically opposite views on organizational structure design and development. First one is based on the opinion that the organizational structure appears spontaneously, over operations in the organization (Janićijević, 1995). Organization faces certain issues and challenges during operating, which leads towards formation of organizational parts and relations between them, in order to find the most efficient and effective way to overcome those challenges. Based on this standpoint, certain authors define organizational structure as a group of patterns, developed and integrated as a mutual activation entity by individuals from the organization (Dulanović and Jaško, 2009). It is a set of prepared solutions for aroused business situations (March and Simon, 1958). Such point of view appears to be very logical, especially when companies are growing from being just small entrepreneurship to large enterprises. Increase in number of employees causes the grouping of people who perform similar jobs into departments. Department formation and formalization of the relations among them are the cornerstones of successful organizational structure development.
However, there is an opposite view which identifies organizational structure as a functional element of every organization, and not just as its attribute. As such, organizational structure should lead to better management of organizational system (Dulanović and Jaško, 2009). This opinion is based on the perspective that organizations exist in order to achieve specific goals and that the role of organizational structure is to facilitate the accomplishment of these goals. It should be compatible with the management concept and with an adequate stability level, in order to ensure efficiency, which is not possible if organizational structure is developed or adjusted spontaneously. Organizational structure presents the way how organizations assign their work and tasks and achieve coordination of realization (Mintzberg, 1979). The problem is that experts usually ignore the second part of this definition in their analysis of the organizational structures. They often take in consideration only vertical relations on organizational schemes, graphical representations of organizational structure, as well as hierarchical relations, control range and other elements that are directly related to management.

However, missing parts of the scheme, horizontal relations among departments, which are necessary for functioning, are often real cause of the problems and they carry significant potential for improvement (Komazec, Todorović 
and Jevtić, 2012). Therefore, there are three key components of organizational structure definition that must be considered equally (Daft, 2004). The first one are reporting relations, including number of hierarchical levels and managers control range. Second is departmentalization, which considers grouping of individuals into departments and, furthermore, departments into organizational units of higher hierarchy level. And the third one is the system that will ensure effective communication, coordination and integration of all the activities across the organization. The first two components describe structural framework, which is necessary for organizational functioning, while the third one focuses on the interactions between employees.

We can see that managers are responsible for organizational structure design, because of their immediate influence. Although there are many external factors that affect organizations and cause changes in organizational structure, managers are those who analyse and evaluate those factors and their impact, and perform necessary measures. They are constantly challenged to design an organizational structure that will lead towards better efficiency and effectiveness of employees (Robins and Coulter, 2005). After all, managers define strategy and set goals, and in this way they directly affect the organizational structure.

\subsection{Process approach to organizational structure design}

Another very important element in organizational design are business processes (Kates and Galbraith, 2007). They permeate through entire organization and create the pathways for satisfying needs of customers. In every organizational system, business processes are core of the transformation mechanism, which is generating new value and enables the organization to differ from competitors (Osterwalder and Pigneur, 2010). Process can be defined a set of interrelated activities that transform inputs into outputs (Scheer, 2009). Taking into account this definition, purpose of each organization can be understood as usage of certain inputs and their transformation to desired outputs, by using set of interrelated activities, which results as services providing or products manufacturing (Komazec, Todorović and Jevtić, 2012). This explains why business processes are essential for the viability of every organization (Carmeli and Tishler, 2004).

Having this in mind, it seems very logical and acceptable to consider business processes as a ground base when designing organizational structure. Process approach considers the application of system of processes in organization, their identification, mutual interaction and management (Filipović and Đurić, 2009). As it was mentioned before, organizational structure is usually designed using the functional units and vertical hierarchical relationships among them. In this way organization managing is influenced. In most cases, organizations are controlled through vertical hierarchical relationships, and functional organizational units are responsible for outputs and business results. Application of process organizational model leads towards identifying all key stakeholders in each business process. It also enables the establishment of an effi- cient system for managing core activities, where duties and responsibilities are defined unequivocally (Todorović et. al, 2013).

One of the most important outputs generated when applying process organizational model are the frontiers between key activities across the functions in the organization. This can be used as the cornerstone for organizational structure improvement, without significant expenses. The idea is to adapt relationships between existing resources to business processes, avoiding large investments. This paper aims to describe cost-effective restructuring on example of one shipping company from Belgrade. All the data presented in this article were generated during the restructuring project which consulting team from Faculty of Organizational Sciences, University of Belgrade, performed in year 2012.

\section{Methodology}

Analysis was based on standard management consulting practice. Content analysis provided research team with basic data about current situation in the company. Existing organizational structure was analysed using widely accepted theoretical models. Existing documentation, consisting of job classifications, job descriptions and quality standards, was analysed carefully.

However, actual tasks divisions were slightly different from those that can be found in formal documents. For this reason, project team had to perform real-time observation, a qualitative research method, which is a very useful tool for hypotheses creation and modification during the project (Todorović, Čudanov and Komazec, 2012). Consultants had to become familiar with the business processes within the company, in order to define specific organizational solutions. Since analysis of all processes through observation requires lot of time, a whole set of meetings with employees was organized. Consulting team held large number of individual meetings with the top-level executives of organizational units, in order to gather more information about functioning of each main part of the company. There were also meetings with employees at lower hierarchical levels, for the purpose of developing solutions at the process level. These employees ought to be the experts for the processes performed in their departments.

This way more accurate image about the situation in the company was created, comparing to content analysis. Described research method provides the opportunity for deep analysis and identification of problems on all hierarchical levels, which is why it presents the strong base for improving organizational structure.

\section{Company analysis}

The core business of analysed company is the transportation of goods on rivers. Its portfolio of services also contains certain non-core businesses, but the income they generate has no significant share in total revenues. The usage of transportation capacity in the company is on a high level, which means that most of the time all the available ships are utilized. However, 
not all human resources in this company are used optimally in this company. Number of employees that perform ship maintenance activities is larger than necessary. There are also certain problems with control of certain activities and costs, especially when it comes to ship maintenance costs, which reduces the ability of the company to gain more profits. And the appropriate level of profitability is necessary for making the fleet investments possible. And constant appropriate condition of ships is precondition for persistent answering to market demands.

The analysed company used to have one of the largest fleets in South-East Europe in the 1980s. In that period, there were more than 2000 employees. However, during 1990s and the crisis in this region, significant part of market share was lost. The fleet became obsolete, while best experts left the company. Smaller business scope was followed with reduced number of employees. One of main problems, which causes the overheads and lack of control, is inadequate organizational structure. Although today the company employees only 399 people, this significant reduction in number of employees was not followed with the appropriate changes in organizational structure. On top hierarchical level, company is divided into four sectors, as presented on Figure 1.

Core processes occur in Commercial and Transportation Sector and Techniques and Maintenance Sector, while noncore activities are performed in other two sectors.

For the purpose of improving market position, fleet investments and modernization are demanded. New management of the company decided to apply cost minimization strategy. This is essential for being competitive on this kind of market, since it is very difficult to offer differentiation in shipping services. Company strategy, as fundamental purpose of operating and starting point in defining the organization, is associated with corresponding organizational structure model (Jevtić, Čudanov and Krivokapić, 2012). Consequently, functional model of organizational structure is present in this company. Within functional organizational structure, all similar activities along with their executors are grouped into one organizational unit, managed by one person, which should be an expert in relevant area of business (Dulanović and Jaško, 2007).

\subsection{Problem identification}

Every model of organizational structure has some advantages and disadvantages, and is applicable in certain situa- tions, while in others is completely inadequate. One of the main disadvantages of functional organizational structure is its tendency to generalize efficiency and contributions of different organizational units to total business success (Hansen and Mouritsen, 2006). It is very difficult to determine individual contributions of different organizational units in organizations where this type of organizational structure is present. In analysed company, Commercial and Transportation Sector generates almost all income. Other sectors, on the other hand, generally produce costs. Nevertheless, these sectors are providing supporting services to Commercial and Transportation Sector, which is their contribution to total business results of the organizational system. It is very difficult to evaluate business success of these sectors, since their services are not sold at the market. For this reason, when functional organizational structure is present, performance evaluation of organizational units that provide support processes is often based only on transactional costs and capacity usage data (Jaško, Jaško and Čudanov, 2010).

In this company, the largest identified problem is the performance of employees from Techniques and Maintenance Sector, together with the undefined relationship of this organizational unit with Commercial and Transportation Sector. Techniques and Maintenance Sector produce high operating costs because of large number of employees. This issue may often cause necessity for restructuring the organization (Čudanov, Jaško and Săvoiu, 2012). About $30 \%$ of all employees are organizationally positioned in this sector. Simply, scope of maintenance required for the ship fleet does not justify such large number of employees working on maintenance. However, if we check their working hours, we will find very high capacity usage in Techniques and Maintenance Sector. The reason for this is lack of control and inadequate power balance.

Techniques and Maintenance Sector, as shown on Figure 2, consists of three organizational units. In Technical Department is kept all the documentation about ship repairs. Employees from this department plan and organize ship repairs. All the maintenance operations are performed in Shipyard, in Production and Control Service and Electronic Service. Current condition of vessel is analysed first, in Technical and Technological Preparation unit, after which is decided whether the repair can be done internally, or it has to be outsourced. After the internal repair, the operations are documented by the employees from Shipyard and forwarded

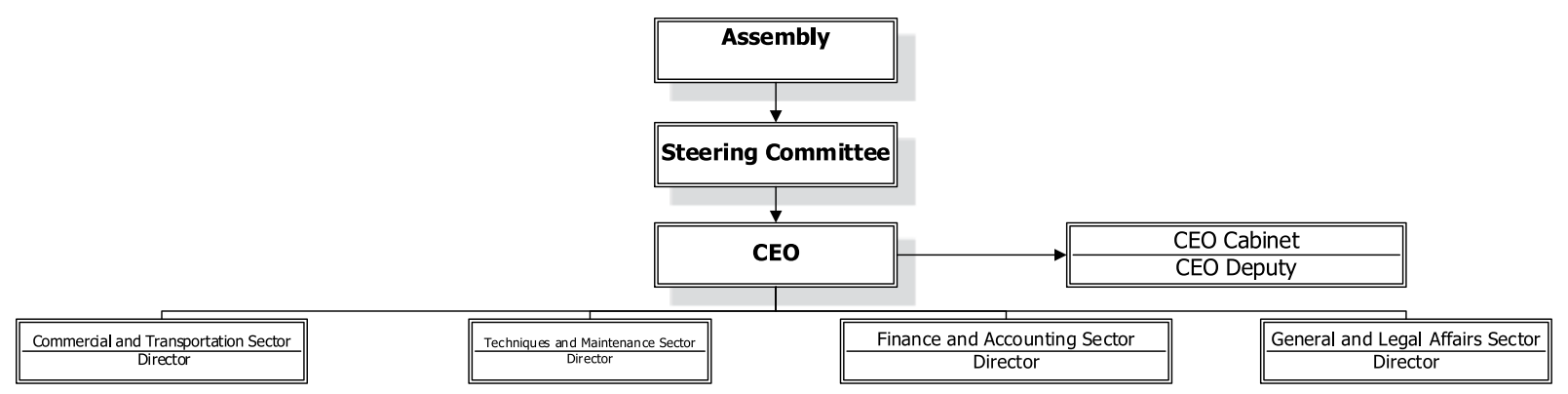

Figure 1: Top hierarchical level of current organizational structure 
to Technical Department. In Cleaning Complex vessels are cleaned and prepared for repairs and sails, and refuelled.

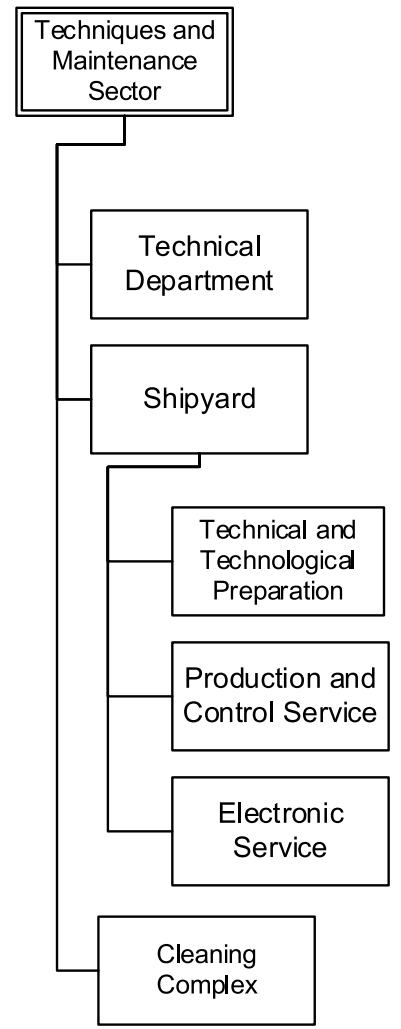

Figure 2: Techniques and Maintenance Sector

Complete ship maintenance process is performed in Techniques and Maintenance Sector, as shown on Figure 3, which is resulting in inadequate concentration of monitoring, management and governance power, unfit for federalist paradigm (Handy, 1992). Commercial and Transportation has almost no control over the maintenance process, although they are in charge for ship exploitation. For this reason, there is a lack of records about provided maintenance services, and about their values, which is very important for evaluating performance of employees from Techniques and Maintenance Sector. They usually magnify their efforts and working hours, which creates wrong image about their performance and about capacity usage in whole sector.

This would be the same situation as if our car service was responsible for arranging regular inspections of our cars instead of ourselves. Not all drivers pass equal distances, so it is not possible for the service to book inspections for drivers. Even if they could follow the distance we travel, they would still have to contact us before making appointment, to check if we are available.

As we can notice, there is no integration and coordination of the core activities between two largest sectors in the organization. Maintenance process potentially can be the cornerstone for coordination between two sectors, but the problem is that it currently occurs almost entirely within just one organizational unit. Application of process approach would overcome this issue.
Another very important problem which had been identified in the company is the control of procurement process. Materials and spare parts procurement used to be done in Commercial Department of Commercial and Transportation Sector. However, that department was only executing procurement process, without analysing validity of procurement requests. All the requests for materials and spare parts are specified in shipyard. After that, Commercial Service sends all the documentation to Finance and Accounting Department, for appropriate record keeping. Finally, there is no adequate control mechanism to determine whether the delivered materials and parts were really used in shipyard the way it was specified in the procurement request. As we can see, there is no clear responsibility for procurement process in the company, which causes large procurement overheads.

\section{Solution}

Each proposal that the consulting team offered was developed using the process approach and with process organizational model as ground base. The goal was to increase control level in maintenance process, in order to reduce the costs caused by malversations during ship repairs and procurement of materials and spare parts.

Consulting team first suggested formation of Maintenance Planning Department in Commercial and Transportation Sector, which ought to be responsible for certain parts of ship maintenance process. In this department could be hired some of the current employees from Technical Department in Techniques and Maintenance Sector, while the others should be transferred from some other department within in Commercial and Transportation Sector, in order to achieve better control of whole process. This new department ought to cover complete first phase of maintenance process, maintenance planning. Records of all maintenance operations performed on a ship would be kept in Maintenance Planning Department. This way, this department would be able to coordinate the maintenance process with the ships exploitation. It was also suggested that this department takes part in the next phases of maintenance process, in order to improve process control. Maintenance Planning Department must consist of maintenance experts, since all works and repairs, before even being started, must be approved as justified by these experts. Their job description should also include field work, through monitoring repairs. This should prevent unnecessary staying of ships in shipyard, as well as the appearance of fictional works. When works are approved, repairers from shipyard should make specification of materials and parts required for further operations. These plans also have to be approved by Maintenance Planning Department. When all this is completed, the specification should be sent to the organizational unit responsible for procurement, in form of formal procurement request. In the very end of the process, Maintenance Planning Department should perform technical inspections of all the operations performed on the ship and compare them to corresponding plans. Such inspections also ought to be formally documented. 




Techniques and Maintenance Sector

Figure 3: Ship maintenance process

\section{Current structure:}

New proposal:

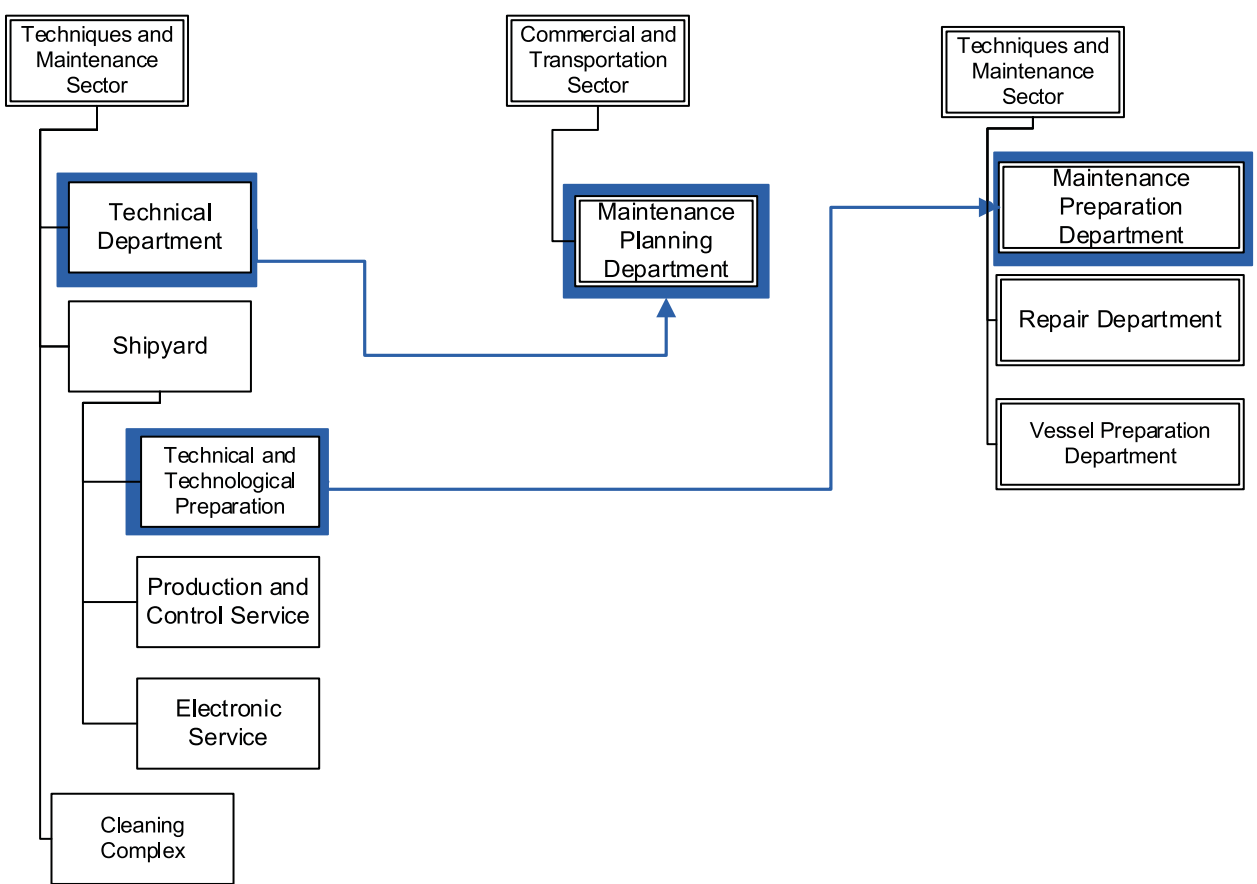

Figure 4: Proposed reorganization of Techniques and Maintenance Sector 
Maintenance Preparation Department, previous Technical and Technological Preparation unit, where condition of vessel is analysed, should be independent from Repair Department, previously named Shipyard. Besides this, new suggested name for Cleaning Complex is Vessels Preparation Department. Described organizational change is presented on Figure 4.

Implementation of suggested organizational changes would significantly reduce the opportunities for malfeasances, since all maintenance costs and operations would be monitored closely. It would also improve the coordination between two largest and most important sectors in the company. Maintenance planning should be moved completely in Commercial and Transportation Sector, where services could be planned in accordance with capacity utilization and ships exploitation. Furthermore, Techniques and Maintenance Sector would then be able to focus on repairs and other maintenance operations exclusively, which were identified as core business in this organizational unit. However, all these activities would be controlled by Maintenance Planning Department, in order to avoid fictive works and reduce the overheads.

Another proposed change in organizational structure that is based on maintenance process is the complete relocation of parts and materials procurement, performed in Procurement and Warehousing Jobs, in Commercial and Transportation Sector, to Economic Affairs Sector, which was previously named Finance and Accounting Sector. Proposed organizational change is presented on Figure 5. In order to point out its importance for the company, this organizational unit ought to be renamed to Procurement and Storage Department. Fuel and oil procurement would continue to be performed within
Commercial and Transportation Sector, more precisely, in Commercial Department, because of its specificity and close connection to everyday operations of the ships.

After such reorganization, the whole responsibility for procurement process would be assigned to single organizational unit, Procurement and Storage Department. For this reason, its employees would be motivated to establish tight control of supply process, which would reduce the possibility for malversations during parts procurement. Besides this, moving this department to Economic Affairs Sector, where all the financial data are kept and analysed, should enable corrective actions and improvements of procurement process.

\section{Conclusion}

Overheads control and minimization can considerably improve profitability of any company. Concrete example presented in this paper describes how the adjustment of organizational structure according to business processes performed in the organization can significantly improve cost control in whole organizational system. Such organizational change does not demand complete organizational transformation, followed by capital investments. Modifications of current business model are neither requested.

Through applying process organizational model, organization will be able to make significant improvements only by harmonizing organizational structure with identified business processes (Komazec, Todorović and Jevtić, 2012). Certain activities should be reassigned to different organizational

\section{New proposal: $\quad$ Current structure:}

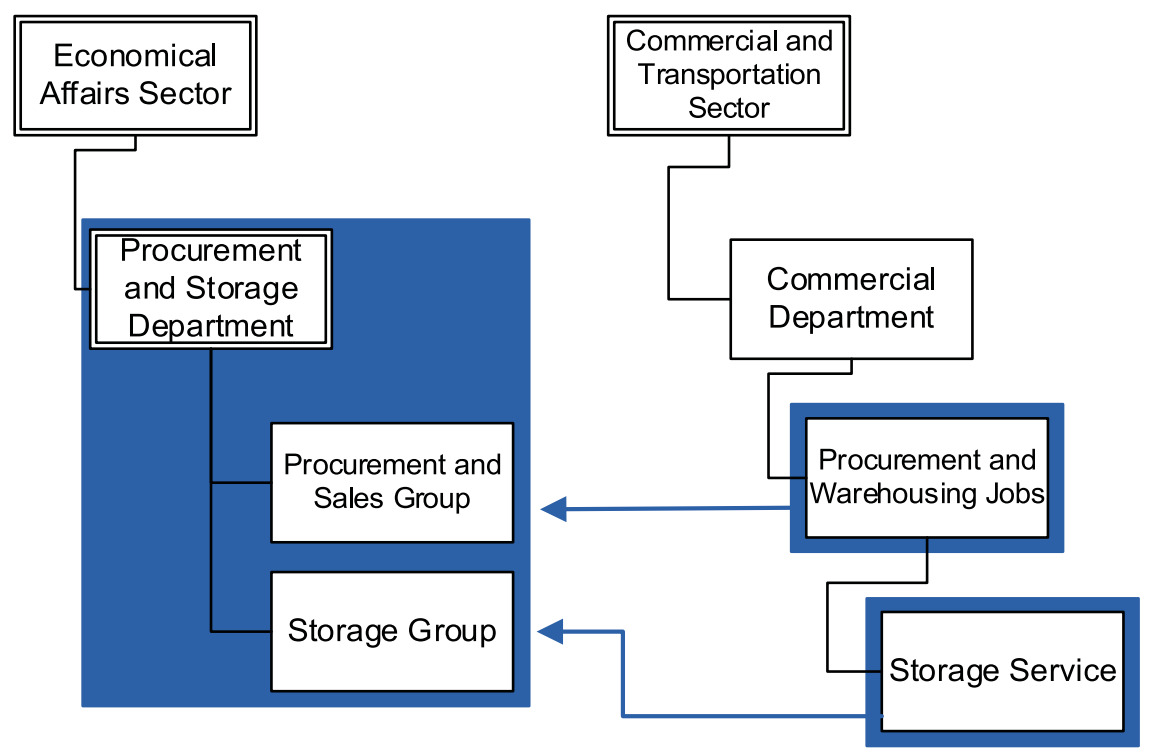

Figure 5: Proposed positions of procurement and storage organizational units 
units, using existing business processes as the ground base for coordination and harmonization of the activities within the organization. From the illustrations shown in this article, we can conclude that application of process approach is one of the most efficient methods for rapid and effective improvements of organizational structure.

\section{Literature}

Carmeli, A. \& Tishler, A. (2004). The Relationships between Intangible Organizational Elements and Organizational Performance, Strategic Management Journal, 25, 1257-1278, http://dx.doi.org/10.1002/smj.428

Čudanov, M., Jaško O. \& Săvoiu G. (2012). Public and Public Utility Enterprises Restructuring: Statistical and Quantitative Aid for Ensuring Human Resource Sustainability, Amfiteatru Economic Journal, 32, 307-322.

Daft, R. L., (2004): Organization theory and Design, $8^{\text {th }}$ edition, Thomson - Southern Western, Mason, Ohio.

Dulanović, Ž. \& Jaško, O. (2007). Organizaciona struktura i promene [Organisational Structure and Changes], University of Belgrade, Faculty of Organizational Sciences.

Dulanović, Ž. \& Jaško, O., (2009): Osnovi organizacije poslovnih sistema [The Basics of Business Systems' Organisation], University of Belgrade, Faculty of Organizational Sciences.

Filipović, J. \& Đurić, M. (2009). Osnove kvaliteta [The Basics of Quality], University of Belgrade, Faculty of Organizational Sciences.

Handy, C. (1992). Balancing Corporate Power: A New Federalist Paper. Harvard Business Review, 70(6), 59-72, http://dx.doi. org/10.1225/92604

Hansen, A. \& Mouritsen, J. (2006). Management Accounting and Operations Management, Understanding the Challenges from Integrated Manufacturing, Handbooks of Management Accounting Research, Vol. 2, pp. 729-752, http://dx.doi. org/10.1016/S1751-3243(06)02011-6

Janićijević, N. (1995). Korporativna transformacija [Corporate Transformation], Timit, Belgrade.

Jaško, O., Jaško, A. \& Čudanov, M., (2010). Impact of Management upon Organizational Network Effectiveness, Management časopis za teoriju i praksu menadžmenta, 16(56), 5-13.

Jevtić, M., Čudanov, M. \& Krivokapić, J. (2012). The Impact of Business Strategy on Organizational Structure, Strategic Management, 17(1), ISSN 1821-3448.

Kates, A., Galbraith, J.R. (2007). Designing Your Organization, Jossey-Bass, San Francisco, USA, pp. 1-71.

Komazec, S., Todorović, I. \& Jevtić, M. (2012). Application of Process Organization Model as a Basis for Organizational Structure Improvement, Strategic Management, Vol. 17, No. 4, pp. 41-49, ISSN 1821-3448.

Kotter, J. P. (1996). Leading change, Harvard Business School Press, Boston, Massachusetts.

March, J. G. \& Simon, H. A. (1958). Organizations, John Wiley, New York.

Mintzberg, H. (1979). The Structuring of Organization, Prentice Hall, Englewood Cliffs, New Jersey.

Osterwalder, A. \& Pigneur, Y. (2010). Business Model Generation, John Wiley \& Sons, New Jersey, USA.

Robins, S. P. \& Coulter, M. (2005). Management, $8^{\text {th }}$ edition, Data Status, Belgrade.

Scheer, A. W. (2009). Business process engineering: reference models for industrial enterprises, Springer-Verlag, Berlin, Germany.
Todorović, I., Čudanov, M. \& Komazec, S. (2012). Interrelationships of Changes in Organizational Structure and Technology. In Proceedings of the $31^{\text {st }}$ International Conference on Organizational Science Development, Portorož, Slovenia, March 21-23, 2012, pp. 1264-1271.

Todorović, I., Komazec, S., Krivokapić, J., Čudanov, M., Jaško, O. \& Marič, M. (2013). Improving control in organization by introducing process organizational model, In Proceedings of the $32^{\text {nd }}$ International Conference on Organizational Science Development, Portorož, Slovenia, March 20-22, 2013, pp. 11221130.

Waterman, R. Jr., Peters, T. \& Phillips, R., (1980). Structure is not organization, Business Horizons, 23(3), 14-26. doi:10.1016/0007-6813(80)90027-0

Ivan Todorović is as teaching associate at Faculty of Organizational Sciences in Belgrade. His major research interests are business system consulting and restructuring, organizational design, organizational change and organizational performance. As the author or co-author, he has published one book and more than 20 articles at scientific journals and conference proceedings. He has also participated in 5 consulting projects. He was member of the team that won HULT Global Case Challenge in London in 2012, and he also won Balkan Case Challenge in Vienna in 2010. He was jury member at several local and international business case study competitions.

Stefan Komazec works as teaching associate at Faculty of Organizational Sciences, University of Belgrade. His major research interests are organizational design, organizational change, business system restructuring, organizational performance and quality management. He has published more than 20 articles at scientific journals and conferences. Also is the co-author of one book. He is one of the founders and project leader of international student sport tournament EuroBelgrade, which is organized every year by Faculty of Organizational Sciences. He has been involved on 5 consulting projects from the field of organizational design.

Miha Marič graduated in 2006 and in the following year (2007) received his master's degree at the Faculty of Economics, University of Ljubljana. He is currently employed as a teaching assistant at the Faculty of Organizational Sciences, University of Maribor and is currently concluding his Ph.D. studies at the Faculty of Economics, University of Ljubljana. His research interests are: power, leadership, organizational behaviour, HRM, management, organization.

Jovan Krivokapić is teaching assistant at the Faculty of Organizational Sciences in Belgrade, in Department for Business Systems Organization. He graduated at this faculty in 2007, and in 2009 he became a master engineer of organizational sciences. Currently, he is a PhD student. His areas of interest are organizational design and restructuring, business consulting and special events management. As the author or co-author, he has published 3 books and more than 25 papers in scientific journals and conferences. He has participated in more than 10 consulting and research projects and some of them were of wide social significance. 